\title{
STUDY ON IMPROVING THE NUTRITIONAL VALUE OF FEED FILLERS USING CHEMICAL TREATMENTS
}

\section{YOUSIF JUMMA ABDURAHMAN ADAM AND MAEN TAHER IDELL *}

Biology Department, Faculty of Science \& Arts (Qelwah), Al-Baha University, Saudi Arabia

*Corresponding Author: Maen Taher Idell: E Mail: mtidell@bu.edu.com

Received $2^{\text {nd }}$ Feb. 2018; Revised 27 $7^{\text {th }}$ Feb. 2018; Accepted $26^{\text {th }}$ March 2018; Available online $1^{\text {st }}$ May 2018

DOI: https://doi.org/10.31032/IJBPAS/2018/7.5.4453

\begin{abstract}
This study was conducted to improve the value of nutrition for small ruminants of sheep as well as goats (whether they was lamb breeding or feathers caring or mothers caring). Chemical components were determined before the chemical treatment with urea; the feeding materials were sprayed on a high quality plastic sheet with urea solution (10\% urea and 46\% nitrogen were dissolved in 50 liter of distilled water), from this solution $10 \%$ per $100 \mathrm{~kg}$ dried food (Barely hay and wheat hay) was used after 20 minutes of intensive spraying. The feeding material was tightly covered with the plastic cover, and the air was discharged by using the German vacuum machine. The plastic bags were tightly covered and kept for 30days. Lids were opened and the fodder was fed for four days to dispose the ammonia and expose the oxygen in order to complete the chemical transformation process. The chemical composition of the fodder samples had been obtained before and after the urea treatment was estimated by approximate analysis method adopted in such researched DUNCAN.0. Weight gain was calculated after the period of nine-weeks started from the beginning of the food treatment. Food conversion efficiency of the studied individuals was collected according to the research parameters. The statistical analysis of variance was used to calculate the variance according to the full random design adopted in this study. The averages were compared based on the DUNCAN test
\end{abstract}

The results have shown that the raw protein content in $10 \%$ feed in urea flour improved in barley and wheat production by $123 \%$ and $125 \%$ respectively on $(3.25 \%$ $7.25 \%)$ and $(3.40 \%-7.65 \%)$. The percentage of raw fiber in both barley and wheat straw are 
declined by $16 \%$ and $14.8 \%$ respectively on $35.45 \%$ and $30.50 \%$ and $35.60 \%$ to $31 \%$. Also increasing in feed consumption after treatment was observed and this goes back to the improvement in its acceptance and animals like.

\section{Keywords: Feed Fillers, livestock, Feeding Material}

\section{INTRODUCTION}

Many studies were focused on research trends in the needs of ruminants for protein and energy as they are important in raising the level of animal performance and achieving the maximum possible yield [1-2]. It is an important to note that the feeding provision with concentrated feeding in ruminant animal prevents the formation of a mass of dough that causes dyspepsia in digestion as well as physiological aspects related to the feeling of fullness of the abdomen and the start of real digestion. The agricultural sector is the spearhead for food security and the animal aspect is an important part of it. Sheep are the mainstay of agricultural animals in Saudi Arabia, contributing $75 \%$ of the total meat production and it is generally less productive than other agricultural animals. So, the attempt to improve their productive efficiency is mainly related to improving their reproductive efficiency in terms of the number of births and increasing birth rate [3]. The food security of any community depends on the main peasantry, natural grazing and therefore on livestock in general. Food security also depends particularly on the cultivation of small ruminants on natural pastures for the filling of the shortage of animal protein. Al-Baha region has a large livestock wealth of sheep as well as goats. It has been raised in ancient ways and methods did not follow modern intensive or semi-intensive way of breeding, nutrition and care. They continued their work with their modest profits (in spite of high price of local meats compared with imported meat) relaying on the government support provided on concentrated feeds, the vision of any investment in the animal production sector without this support will be disastrous because of the nutrition of these animals costs more than $70 \%$ of production expenses. The magical and semi-intensive breeding of these animals is the pattern in the area of Albaha that results in the natural grazing which is the major role in the conservation of livestock and in significantly reducing production costs [4]. It was noted that the degradation of rangelands resulting from overgrazing.

\section{MATERIALS AND METHODS}

The applied samples were obtained and used in nutrition for small ruminants of sheep and goats (whether they are lamb breeding or care feathers or mothers caring). The chemical components were 
determined before the treatment with urea, $10 \%$ urea and $46 \%$ nitrogen were dissolved in 50 liter of distilled water to prepare the urea solution. $10 \%$ of the prepared urea solution was used for each $100 \mathrm{Kg}$ of dry food. The feeding materials were sprayed on a high quality plastic sheet for 20 minutes of intensive spraying (To give the feed material an opportunity to absorb), a special sprayer was used to deliver the chemical used for all feed fodder, The food material was tightly closed with the plastic cover and the air was removed by using the German vacuum machine. The plastic were covered to prevent any leakage of ammonia or air entering during the experimental period of 30-days. The lids were then opened and the fodder was fed for four days to dispose the ammonia and expose the oxygen to complete the chemical transformation process. The chemical composition of the fodder samples obtained before and after the urea treatment was estimated by the approximate analysis method adopted in such research DUNCAN The weight gain was calculated after the nine-week period (the week of adaptation to the treated meal and eight weeks of experiment) and the food conversion efficiency of the studied individuals and the research parameters used were calculated. The analysis of variance was used to calculate the variance of the statistical program according to the full random design adopted in this study. The averages were compared based on the DUNCAN test.

\section{RESULTS AND DISCUSSION}

\section{Analysis of chemical content}

Table (1) shows that the raw protein content in $10 \%$ feed in urea flour improved in barley and wheat production by $123 \%$ and $125 \%$ respectively on $(3.25 \%-7.25 \%)$ and $(3.40 \%-7.65 \%)$. The percentage of raw fiber in both barley and wheat straw declined by $16 \%$ and $14.8 \%$ respectively on $35.45 \%$ and $30.50 \%$ and $35.60 \%$ to $31.00 \%$. Gupta \& Murdia [5] referred in experiment used the chemical treatment of urea with different concentrations, indicates the improvement in the percentage of crude protein and the decrease in the ratio of raw fiber in the cane plant used in fattening meat calves. Similarly here it was also observed that the superiority of wheat hay before and after treatment with urea to hay barley after and before treatment with urea.

From table (2) it was observed that there was an increasing in feed consumption after treatment, this goes back to the improvement in its acceptance and animals like, which is considered as a good indicator of the relevance and importance of the chemical urea treatment of feed fillers to improve nutritional content. Consumption has increased both of barley and wheat hay at the rate of $22 \%$ and $26 \%$ respectively, $\mathrm{P}<\mathrm{O} .05)$ ). This corresponds 
to the previous study of Narayan et al [6]

and Trishna et al [7] when feeding calves

on feed corn cane filler treatment with

different levels of urea concentrations indicating an increased rate of consumption when calves were moral difference $\mathrm{P}<$ 0.05 .

Table (1): Shows the chemical content based on the dry matter of barley hay, wheat hay, and ready

\begin{tabular}{|c|c|c|c|c|c|c|c|}
\hline No. & Treated Feeding Materials & $\begin{array}{c}\text { Dry } \\
\text { Material } \\
(\%)\end{array}$ & $\begin{array}{c}\text { Raw } \\
\text { Protein } \\
(\%)\end{array}$ & $\begin{array}{c}\text { Raw } \\
\text { Fiber } \\
(\%)\end{array}$ & $\begin{array}{c}\text { Free Nitrogen } \\
\text { Extract }(\%)\end{array}$ & $\begin{array}{c}\text { Raw Fat } \\
(\%)\end{array}$ & $\begin{array}{c}\text { Ash } \\
(\%)\end{array}$ \\
\hline 1 & Barely hay & 90.64 & 3.25 & 35.45 & 52.25 & 1.60 & 7.50 \\
\hline 2 & $\begin{array}{c}\text { Barely hay after treatment } \\
\text { with urea }\end{array}$ & $\mathbf{8 0 . 9 2}$ & 7.25 & $\mathbf{3 0 . 5 0}$ & $\mathbf{5 1 . 6 0}$ & 2.00 & $\mathbf{8 . 5 0}$ \\
\hline 3 & Wheat hay & $\mathbf{9 2 . 5 0}$ & $\mathbf{3 . 4 0}$ & $\mathbf{3 5 . 6 0}$ & $\mathbf{5 3 . 0 0}$ & 1.75 & 8.00 \\
\hline 4 & $\begin{array}{c}\text { Wheat hay after treatment } \\
\text { with urea }\end{array}$ & $\mathbf{8 3 . 5 0}$ & 7.65 & $\mathbf{3 1 . 0 0}$ & $\mathbf{5 3 . 0 0}$ & $\mathbf{2 . 1 0}$ & $\mathbf{8 . 7 5}$ \\
\hline 5 & Concentrated feed & $\mathbf{8 8 . 0 0}$ & $\mathbf{1 7 . 0 0}$ & 4.00 & 75.00 & 4.10 & 4.00 \\
\hline
\end{tabular}

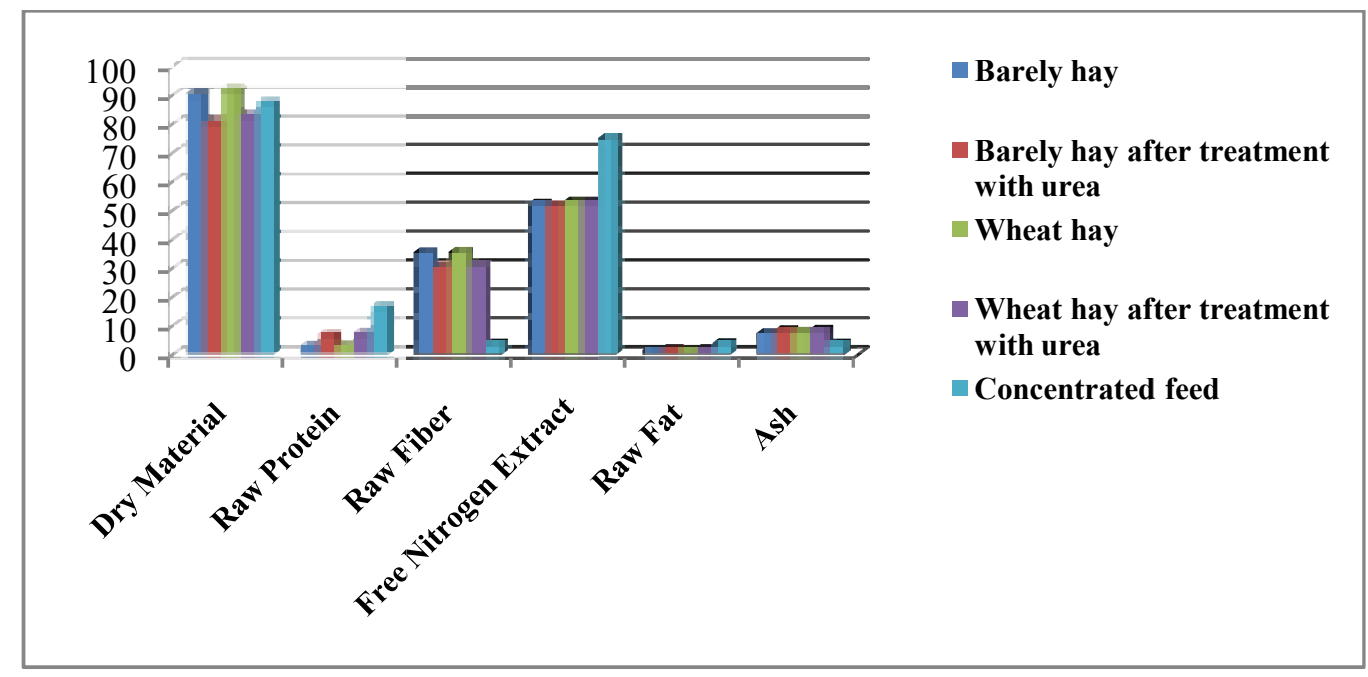

Figure 1: Chemical content based on dry material for barley hay, wheat hay, and ready feed

Table (2) Consumption averages \pm Standard error for both dry matter and raw protein in barley and nonprocessed barley, and processed and uncooked wheat cultivars (gram / head / day)

\begin{tabular}{|c|c|c|c|c|c|}
\hline Statement & Barley Hay & $\begin{array}{c}\text { Barley Hay } \\
\text { After Treatment } \\
\text { With Urea }\end{array}$ & Wheat hay & $\begin{array}{c}\text { Wheat Hay } \\
\text { After Treatment } \\
\text { With Urea }\end{array}$ & Concentrated Feed \\
\hline Dray Material & $\mathbf{4 5 0} \pm \mathbf{1 2 . 2}$ & $\mathbf{5 5 0} \pm \mathbf{1 8 . 1}$ & $\mathbf{4 5 5} \pm \mathbf{1 4 . 0 0}$ & $\mathbf{5 7 5} \pm \mathbf{2 2 . 0 0}$ & $\mathbf{3 0 0} \pm \mathbf{0 . 0 0}$ \\
\hline Raw Protein & $\mathbf{1 4 . 6} \pm \mathbf{0 . 3 9}$ & $\mathbf{3 9 . 8} \pm \mathbf{1 . 3 1}$ & $\mathbf{1 5 . 4} \pm \mathbf{0 . 4 7}$ & $\mathbf{4 3 . 9} \pm \mathbf{1 . 6 8}$ & $\mathbf{5 1 . 0} \pm \mathbf{0 . 0 0}$ \\
\hline
\end{tabular}




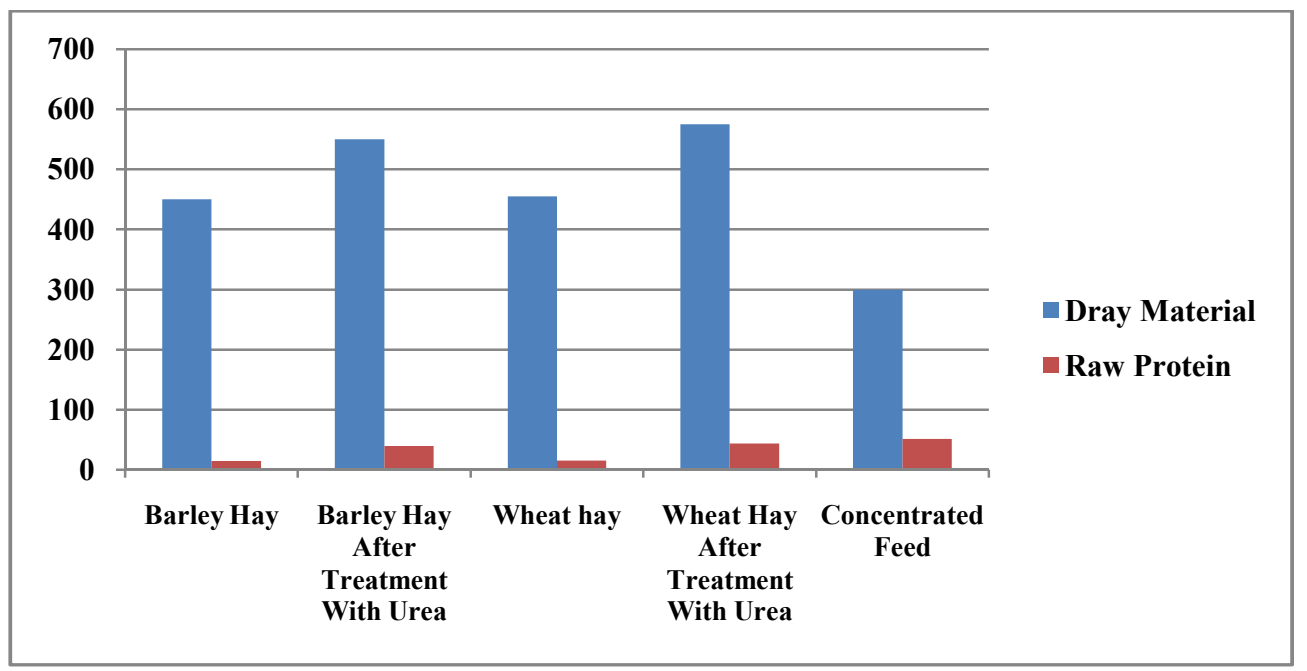

Figure 2: Consumption averages \pm Standard error for dry matter and treated wth barley and nonprocessed barley varieties and processed and uncooked wheat (g/ head / day)

\section{CONCLUSION}

It was noted through the research results obtained that the increase in the consumption rate of chemical treated barley plants about $100 \mathrm{~g}$ per day per head. Similarly the consumption of wheat straw at a rate of $120 \mathrm{~g} /$ day per head of both groups was increased compared to the witness.

\section{REFERENCES}

[1] Wilke PI. Effect of nitrogen supplementation on the utilization of sodium hydroxide treated corn stover by dairy goats. Small Ruminant Research. 1992; 9 (2): 167-71.

[2] Lu CD, Kawas JR, Mahgoub OG. Fibre digestion and utilization in goats. Small Ruminant Research. 2005; 60 (1): 45-52.

[3] Hulet, C. V. "Improving reproductive efficiency in sheep."
In Animal Reproduction, pp. 3140. Allanheld, Osmun \& Co. Publishers, Inc., Montclair, NJ, 1979.

[4] Idell, M and Elhag, F. The Effect of the Melatonin hormone on the Performance of the Ovaries in Naimi Sheep when Exposed to Different Periods of Light International Journal of Science and Research (IJSR). 2017; 6 (2): 1733-1738

[5] Gupta, L. and Murdia, P.C. 2006. Effect of feeding urea treated wheat straw with or without sulphur on voluntary intake and nutrient utilization in crossbred heifers. Indian J. Dairy Sci. 59:2528.

[6] Narayan, D., K. Sharma and U. Anglia. 2004. Nutritional 
evaluation of lentil straw and urea treated wheat straw in goats and lactating buffaloes. AsianAustralian J. Anim. Sci. 17 (11): 1529-1534

[7] Trishna, B. K., D. Sanjeeb, B.K. Rajeeb, and S.D. Rijusmita. 2012.
Growth performance and nutrient utilization of growing calves with urea treated wheat straw based ration. Indian J. Dairy Science. $65,5: 435-438$ 